\title{
Feminilidade e Novas Formas de Subjetivação
}

SILVIA ALEXIM NUNES •

\begin{abstract}
ARÁN, Márcia
O AVESSO DO AVESSO: feminilidade e novas formas de subjetivação

Rio de Janeiro: Garamond, 2006
\end{abstract}

A questão da diferença sexual e da feminilidade éa ainda hoje um problema fundamental para todos aqueles que se aventuram no território da psicanálise. Sabemos que desde o início de seu percurso Freud procurou dar conta das vicissitudes da constituição da subjetividade de homens e mulheres, enquanto sujeitos sexuados, tecendo ao longo de seu percurso caminhos diversos, polêmicos e contraditórios.

Em suas elaborações podemos perceber duas vertentes através das quais ele problematizou a diferença sexual e o feminino. Construiu uma teoria sobre a sexualidade na qual o falo foi pensado como o ordenador da sexualidade humana, dando a essa vertente um caráter universal. Mas paralelamente, ao longo de sua trajetória, explorou outros territórios onde a questão da intensidade pulsional, de uma experiência erótica não subsumida à lógica fálica, ganhou força, apontando para um outro registro psíquico a partir do qual é possível pensar o processo de subjetivação como uma experiência antes de tudo singular. É nessa vertente que em "Análise terminável e interminável”, questionandose sobre os impasses da clínica, Freud reabriu uma reflexão sobre a feminilidade, apontando para os limites da prática psicanalítica centrada na referência ao falo.

Confrontados com as mudanças na cultura que afetam os recortes tradicionais de masculinidade e feminilidade construídos na modernidade, alguns psicanalistas têm procurado iluminar esse território, resgatando a feminilidade do registro da falta e da insuficiência, apontando sua potência produtiva, positivando-a enquanto um registro psíquico fundamental da experiência humana. 
Nesse contexto se inscreve o trabalho de Márcia Arán. Em O avesso do avesso: feminilidade e novas formas de subjetivação, a autora vai explorar o território da feminilidade, com o objetivo de pensar as novas formas de subjetivação na cultura contemporânea. O livro é composto por seis capítulos, nos quais, a partir de diferentes fios, a autora vai construir e desenvolver suas hipóteses.

No primeiro capítulo, partindo de uma reflexão sobre as mudanças ocorridas no campo das sexualidades, onde o dualismo homem - público / mulher - privado já não se sustenta, a autora procura mostrar como os deslocamentos do feminino, em meio à crise do masculino, constituem um novo paradigma para pensar a diferença entre os sexos.

No segundo capítulo, retomando o texto freudiano "O Mal-estar na civilização", ressalta que Freud se refere a um impasse na economia subjetiva que conjuga a renúncia pulsional com o afastamento do território feminino, o que corresponderia à exigência do processo civilizador na modernidade, calcado na renúncia do particular em nome da perpetuação de um universal.

No terceiro capítulo, recorrendo ainda a Freud e propondo uma análise crítica do "Caso de uma jovem homossexual", a autora procura demonstrar que o pressuposto da inveja do pênis como destino da sexualidade feminina evita o reconhecimento da diferença que, neste caso, aparece como sendo a especificidade da relação entre uma menina e sua mãe.

No quarto capítulo, acompanhando a construção dos conceitos que constituem as "fórmulas de sexuação", procura pensar até que ponto Lacan confere ao feminino um real estatuto de alteridade.

Nos dois últimos capítulos, a autora se propõe a recuperar e positivar o conceito de feminilidade como uma crítica ao modelo da castração e, para além da teoria sobre a diferença sexual vigente na psicanálise, procura elaborar uma "metapsicologia da alteridade" como sugestão para pensar novas formas de sociabilidade a partir das experiências singulares.

Para realizar essa empreitada, Márcia Arán vai aproximar psicanálise e história, recorrendo a três importantes pensadores: Michel Foucault, Geneviève Fraisse e Walter Benjamin. Nessa trajetória aponta como o feminino pode ser considerado o outro historicamente negado e recalcado, não apenas a partir do que se convencionou chamar "dominação masculina", mas também por uma forma de sociabilidade que se constituiu a partir do domínio da natureza, seja do mundo real ou da natureza "dentro de si", isto é, da experiência pulsional. 
É nessa perspectiva que vai procurar rediscutir as formulações psicanalíticas sobre a diferença sexual e a feminilidade, tentando apontar novas possibilidades de diferenciação e um novo esboço do feminino. Partindo da idéia de que tanto para Freud quanto para Lacan a questão da diferença se articula em torno da questão de ter ou não o falo, o que considera uma versão masculina da diferença, Márcia vai apontar como, em Freud, a única possibilidade de destino para a sexualidade feminina acaba sendo a inveja do pênis, tendo na sua versão positiva a maternidade e na sua versão negativa a renúncia e a virilização. Em relação a Lacan, a partir da problematização de algumas de suas teses, tais como a construção da idéia da "não-relação sexual", da mulher como "não-toda na função fálica" e do "gozo a mais", questiona se o autor confere de fato ao feminino o estatuto real de alteridade ou permanece preso a uma tradição ocidental onde $o$ Outro nunca se solta das amarras daquele que se pretende Um e, como consequiência, ou expulsa a diferença ou faz dela sua refém.

Indo ainda mais além, tomando como referência o debate sobre a feminilidade proposto por alguns teóricos atuais no campo da psicanálise, como Monique Schneider, Monique David-Ménard e Joel Birman, a autora esboça suma "metapsicologia da alteridade". Para isso, a partir da análise de algumas passagens da obra freudiana, procurou pensar a noção de alteridade na psicanálise, tomando como alteridade a possibilidade de abertura, de convivência com o que há de estranho em si e no outro, o que significa sempre um abalo nos limites do eu. Nessa perspectiva, nas palavras da autora, a sexuação é alguma coisa que se produz a cada momento, pois sempre se faz provisoriamente a partir do encontro com o outro. Esta é uma possibilidade que a experiência feminina traz consigo, presentificando, assim, na crise da modernidade, a potencialidade do novo.

A psicanálise se constituiu em torno da passionalidade do corpo da histérica, acolhendo e dando ouvidos aos sofrimentos femininos. Mas se a escuta do feminino marcou o seu início, seu destino na atualidade depende da possibilidade de romper definitivamente com um modelo universalista de pensar as diferenças e a subjetividade, o que passa necessariamente por uma leitura do erotismo centrada na feminilidade e na singularidade.

É para essa aventura que nos conduz Márcia Arán nesse livro instigante, ousado, marcado pela perspicácia, sensibilidade e erudição. 


\section{NOTA}

- Psicanalista, membro do Espaço Brasileiro de Estudos Psicanalíticos, doutora em Saúde Coletiva pelo IMS-UERJ, autora do livro O corpo do diabo entre a cruz e a caldeirinha: um estudo sobre a mulher, o masoquismo e a feminilidade. Rio de Janeiro: Civilização Brasileira, 2000. Endereço eletrônico: silviaalexim@uol.com.br. 